Witold Jedynak ${ }^{1}$

Uniwersytet Rzeszowski

Instytut Socjologii

\title{
Nauczanie religii w polskich szkołach - sukces czy porażka?
}

\section{Wprowadzenie}

Według dokumentów kościelnych, katecheza jest działaniem Kościoła, powiązanym z całą jego duszpasterską i misyjną aktywnością. W adhortacji „Catechesi tradendae" (1979 r.), wyjaśniającej rolę katechizacji w działalności ewangelizacyjnej Kościoła katolickiego, katecheza została określona jako wychowanie w wierze, obejmujące nauczanie doktryny chrześcijańskiej, przekazywane w sposób systematyczny i całościowy, dla wprowadzenia wierzących w pełnię życia chrześcijańskiego ${ }^{2}$. Wyróżnione zostały zatem trzy podstawowe zadania katechezy: wychowanie w wierze, nauczanie doktryny chrześcijańskiej oraz wtajemniczenie chrześcijańskie ${ }^{3}$. Katecheza jest procesem wzrastania w wierze i zmierza do kształtowania dojrzałej wspólnoty chrześcijańskiej .

${ }^{1}$ Ksiądz Witold Jedynak, prof. UR; doktorat 1998 r., habilitacja 2007 r., od 2008 r. profesor nadzwyczajny, od 2009 zastępca dyrektora Instytutu Socjologii Uniwersytetu Rzeszowskiego, od 2012 r. dyrektor Instytutu Socjologii Uniwersytetu Rzeszowskiego, od 2008 kierownik Zakładu Polityki Społecznej i Pracy Socjalnej; prowadzi badania w zakresie socjologii religii, socjologii moralności, teologii pastoralnej, pracy socjalnej.

Autor artykułu przez siedemnaście lat (1991-2008) jako katecheta prowadził nauczanie religii w szkołach publicznych.

2 Jan Paweł II, Adhortacja apostolska o katechizacji w naszych czasach (Catechesi tradendae), w: Adhortacje ojca świętego Jana Pawła II, t. 1, Wydawnictwo św. Stanisława B.M. Archidiecezji Krakowskiej, Wydawnictwo M, Kraków 1996, s. 17 (nr 18); Katechizm Kościoła katolickiego, Wydawnictwo Pallottinum, Poznań 1994, s. 12 (nr 5).

${ }^{3}$ Dyrektorium ogólne o katechizacji (1997 r.) wylicza podstawowe zadania katechezy: rozwijanie poznania wiary, wychowanie liturgiczne, formacja moralna, nauczanie modlitwy, wychowanie do życia wspólnotowego, wprowadzenie do misji. Zob. Kongregacja ds. Duchowieństwa, Dyrektorium ogólne o katechizacji, Pallottinum 1998, s. 69-72 (nr 85-86).

${ }^{4}$ M.P. Domingues, Parafia jako miejsce ewangelizacji, „Kolekcja Communio” 8(1993), s. $310-311$. 
Podstawową i najważniejszą przestrzenią, w której powinna dokonywać się katechizacja wiernych, jest parafia. Do zadań duszpasterskich parafii należy bowiem podejmowanie działań mających na celu podtrzymywanie życia wspólnotowego społeczności religijnej poprzez wzmacnianie łączność z Bogiem i więzi międzyludzkich w oparciu o życie sakramentalne, znajomość Chrystusa i jego nauki oraz świadomość przynależności do Kościoła i odpowiedzialności za niego. Adhortacja „Christifideles laici” przypomina, że pradawna i czcigodna struktura, jaką jest parafia, spełnia aktualnie niezastąpioną misję. Parafia scala wiernych w pierwszą i podstawową wspólnotę, przysposabiając ich do życia liturgicznego, podtrzymuje i ożywia wiarę wiernych, zachęca do praktykowania miłości bliźniego oraz zapewnia dzieciom i młodzieży przekaz zbawczej nauki Chrystusa ${ }^{5}$.

W ostatnich kilkudziesięciu latach parafie katolickie w Polsce traktowały katechezę jako ważny instrument oddziaływania duszpasterskiego na wiernych, a zwłaszcza na dzieci i młodzież. W okresie PRL-u parafie katolickie prowadziły katechizację młodego pokolenia, wykorzystując do tego celu przede wszystkim własne budynki (punkty katechetyczne i kościoły). Upadek komunizmu i transformacja ustrojowa stworzyły nowe możliwości realizowania katechezy poprzez jej prowadzenie w szkołach publicznych. Zmienione okoliczności determinowały konieczność wypracowania nowego modelu katechezy, uwzględniającego uwarunkowania szkolne. Zakładano, że katecheza w polskiej szkole będzie częścią procesu ewangelizacji, znajdującego dopełnienie w katechezie parafialnej. W ten sposób miał zostać zrealizowany postulat Kościoła o komplementarności szkolnego nauczania religii i katechezy parafialnej ${ }^{6}$. Ponieważ nauczanie religii w polskiej szkole ma bardzo wyraźnie zarysowany profil katechetyczny, dlatego w niniejszym opracowaniu będzie nazywane katechezą szkolną lub katechezą w szkole, w celu odróżnienia od katechezy parafialnej.

Wprowadzenie nauczania religii do szkół publicznych w 1990 roku stało się wydarzeniem powszechnie komentowanym i dyskutowanym w polskim społeczeństwie. Generowało również spory polityczne i światopoglądowe, zwłaszcza pomiędzy przedstawicielami partii politycznych. Temat nauczania religii w polskich szkołach jest kwestią, która nadal wywołuje napięcia i polemiki, w tym w debatach ideologicznych.

Ze względu na aktualność problematyki i jej znaczenie społeczne autor uczynił katechezę szkolną przedmiotem swoich badań. Celem niniejszego opracowania jest próba oceny nauczania religii w polskich szkołach $\mathrm{w}$ oparciu analizę

5 Jan Paweł II, Christifideles laici, Wydawnictwo Wrocławskiej Księgarni Archidiecezjalnej, Wrocław 1990, nr 26, s. 68.

${ }^{6}$ Konferencja Episkopatu Polski, Dyrektorium katechetyczne Kościoła katolickiego w Polsce, Warszawa 2001, s. 16. Zob. P. Tomasik, Religia $w$ dialogu z edukacją. Studium na temat korelacji nauczania religii katolickiej z polska edukacją szkolna, Wydawnictwo Salezjańskie, Warszawa 2004, s. 39-43. 
źródeł zastanych. Istotne znaczenie dla zrealizowania celu badań będzie miało znalezienie odpowiedzi na pytanie: czy nauczanie religii w polskich szkołach można uznać za sukces duszpasterski Kościoła katolickiego, czy raczej za jego porażkę? Rozwiązując problem badawczy, autor poddał analizie następujące aspekty badanego procesu społecznego: poziom zaangażowania Kościoła w katechizację szkolną, społeczne poparcie dla nauczania religii w szkole, frekwencję uczniów na katechezie szkolnej oraz ocenę jej jakości. Dokonano przeglądu wyników badań socjologicznych na temat nauczania religii w szkołach, zwracając szczególną uwagę na wypowiedzi uczniów i rodziców, dotyczące tej formy katechezy. Ponadto podjęto próbę ustalenia, na ile katecheza realizowana w polskich szkołach odpowiada oczekiwaniom społecznym. Przedstawiono także różne stanowiska odnoszące się do obecności katechezy w szkole publicznej.

\section{Zaangażowanie Kościoła w nauczanie religii na terenie szkoły}

Kościół w Polsce przywiązywał dużą wagę do katechizacji dzieci i młodzieży. W okresie PRL-u, po usunięciu nauczania religii ze szkół, podmiotem katechezy oraz miejscem jej realizowania były parafie. Przygotowanie organizacyjne parafii do prowadzenia katechizacji było zróżnicowane. Wiele z nich, zwłaszcza w dużych miastach, nie posiadało wykwalifikowanej kadry oraz odpowiednich pomieszczeń do nauczania religii. Dlatego też zasięg działalności katechetycznej parafii był ograniczony. Dla przykładu, w archidiecezji warszawskiej w roku szkolnym 1970/71 nauczaniem religii było objętych 65\% uczniów szkół podstawowych, 9\% licealistów i 45\% uczniów techników i zasadniczych szkół zawodowych?

Parafie katolickie podejmowały zabiegi w celu zwiększenia oddziaływania na młode pokolenie przez objęcie go katechizacją. Efektem tych starań była systematycznie wzrastająca liczba katechetów ${ }^{8}$ i punktów katechetycznych ${ }^{9}$. Intensyfikacja działalności katechetycznej nie była łatwa do zrealizowania w PRL-u, gdyż Kościół funkcjonował w realiach państwa socjalistycznego, w którym władze prowadziły represyjną politykę wyznaniową i administracyjnie eliminowały religię z życia publicznego.

${ }^{7}$ K. Koseła, Religia przy tablicy - postawy wobec lekcji religii w szkołach, w: Szkoła czy parafia? Nauka religii $w$ szkole $w$ świetle badań socjologicznych, red. K. Kiciński, K. Koseła, W. Pawlik, Zakład Wydawniczy Nomos, Kraków 1995, s. 102.

${ }^{8}$ E. Jarmoch, K. Rosa, Religia w szkołach i katechizacja, w: Kościół katolicki w Polsce. Rocznik statystyczny, red. L. Adamczuk, W. Zdaniewicz, Główny Urząd Statystyczny, Zakład Socjologii Religii SAC, Warszawa 1991, s. 257.

${ }_{9}$ L. Adamczuk, Nauczanie religii w Polsce 1945-1999, w: Kościót i religijność Polaków 1945-1999, red. W. Zdaniewicz, T. Zembrzuski, Instytut Statystyki Kościoła Katolickiego SAC, Warszawa 2000, s. 242; E. Jarmoch, K. Rosa, dz. cyt., s. 257-258. 
Pomimo negatywnego nastawienia władz komunistycznych do nauczania religii, spotykało się ono z powszechnym poparciem społeczeństwa polskiego. Najwyższe gremia partyjne były zaniepokojone wynikami badań socjologicznych zrealizowanych w 1983 r. przez Akademię Nauk Społecznych PZPR, z których wynikało, że 94,6\% ogółu badanych Polaków popierało posyłanie dzieci na katechezę, by wychowywać młode pokolenie w duchu wartości katolickich. Według tych badań, aż 92,1\% członków rządzącej partii uważało, że dzieci należy posyłać na lekcje religii, gdyż są one najlepszą formą wychowania, przysposabiającą młode pokolenie do życia w rodzinie i w społeczności lokalnej. Badani członkowie PZPR-u byli przekonani, że Kościół katolicki jest instytucją W największym stopniu predestynowaną do kształtowania moralności młodego pokolenia, ponieważ niczego złego nie uczy, wręcz przeciwnie, przekazuje zasady moralne oraz wychowuje dzieci do szacunku dla rodziców, osób starszych, drugiego człowieka ${ }^{10}$.

Olbrzymie poparcie społeczne deklarowane w PRL-u dla posyłania dzieci i młodzieży na katechezę utwierdzało przedstawicieli hierarchii kościelnej i katolików świeckich w przekonaniu, że po upadku komunizmu katecheza powinna powrócić do szkół, z których siłowo została usunięta. Duchowni wraz z katolikami świeckimi zaangażowali się w działania, które miały przekonać władze państwowe i społeczeństwo dla poparcia tej idei ${ }^{11}$. Środowiska kościelne przywrócenie katechezy do szkół postrzegały jako naprawienie jednej z wielu krzywd, które spotkały społeczeństwo w czasach systemu totalitarnego ${ }^{12}$. Zakładano, że reaktywowanie nauczania religii w szkołach zostanie przyjęte przez społeczeństwo z zadowoleniem, gdyż umożliwi dzieciom i młodzieży powszechny dostęp do korzystania $\mathrm{z}$ tej formy kształcenia i wychowania religijnego, a także pozytywnie wpłynie na zachowanie ciągłości narodowej tradycji, kultury oraz pozwoli budować przyszłość społeczeństwa na zasadach moralnych ${ }^{13}$.

Zaangażowanie środowisk kościelnych na rzecz powrotu nauczania religii do szkół przyniosło zamierzony skutek. Katechezę wprowadzono do przedszkoli i szkół w roku szkolnym 1990/1991 na podstawie instrukcji Ministra Edukacji

${ }^{10}$ Dokument 32: Analiza postaw członków PZPR wobec religii opracowana w Akademii Nauk Społecznych PZPR (lipiec 1985 r.), w: Tajne dokumenty Państwo - Kościół 1980-1989, Wydawnictwo Aneks \& Polityka, Londyn-Warszawa 1993, s. 434-435. Zob. T. Szawiel, Religijność i jej korelaty, w: Ciagłość i zmiana tradycji kulturowej, red. S. Nowak, Państwowe Wydawnictwo Naukowe, Warszawa 1970, s. 242-243, 261.

${ }^{11}$ Komunikat 240 Konferencji Plenarnej Episkopatu Polski (Warszawa, 2 maja 1990 r.), w: Komunikaty Konferencji Episkopatu Polski 1945-2000, opr. J. Żaryn, Sekretariat Konferencji Episkopatu Polski, Pallottinum, Warszawa 2006, s. 353.

${ }^{12}$ List pasterski episkopatu Polski w sprawie powrotu katechizacji do szkoły polskiej, w: Listy Pasterskie Episkopatu Polski 1945-2000, red. P. Libera, A. Rybicki, S. Łącki, cz. 2, Wydawnictwo Michalineum, Marki 2003, s. 1651.

13 Tamże, s. 1651-1653. 
Narodowej z 3 sierpnia 1990 r. W szkołach podstawowych dzieci brały udział w katechizacji szkolnej za zgodą rodziców, natomiast w szkołach średnich sami uczniowie po osiągnięciu pełnoletniości decydowali o uczestnictwie w nauczaniu religii $^{14}$.

W kręgach kościelnych wyrażano przekonanie, że ,instrukcja była aktem sprawiedliwości dziejowej”, gdyż przywróciła katechezę szkole, z której władze komunistyczne usunęly ją przemocą prawie 40 lat wcześniej ${ }^{15}$. Biskupi polscy uważali, że umożliwienie dzieciom i młodzieży uczestnictwa w katechezie szkolnej jest przejawem umiejętnego korzystania przez naród z daru wolności, nie tylko w wymiarze politycznym, ale również w sferze praw człowieka do swobodnego wyznawania religii ${ }^{16}$.

Przesłanie biskupów skierowane do polskiego społeczeństwa spotkało się jednak ze sprzeciwem różnych środowisk, dla których powrót religii do szkół oznaczał naruszenie świeckiego charakteru szkoły. Lekcje religii w szkole były postrzegane jako forma socjalizacji moralnej, opartej na motywacji religijnej ${ }^{17}$. Nauczanie religii w szkole publicznej stało się przedmiotem długoletnich sporów, podczas których jego zwolennicy i przeciwnicy przywoływali argumenty na uzasadnienie swoich racji ${ }^{18}$.

Podstawy prawne nauczania religii w polskich szkołach były zaskarżane do Trybunału Konstytucyjnego. Podnoszono, że naruszają świecki charakter szkoły, a zwłaszcza zasadę wolności sumienia i wyznania ${ }^{19}$. Środowiska kościelne zdecydowanie protestowały przeciwko próbom ponownego usunięcia religii ze szkół. Odwoływano się do standardów demokratycznych obwiązujących w wielu państwach o ugruntowanej demokracji, w których religia jest nauczana w szkołach publicznych, a jej obecność w szkolnym systemie kształcenia oznacza, że państwo szanuje wolność religijną obywateli w przestrzeni publicznej. Gdy w polskich szkołach przywrócono katechezę, była ona już obowiązkowym przedmiotem w Wielkiej Brytanii, Niemczech, Belgii, Holandii, Austrii, Danii, Finlandii, Norwegii, Grecji, Irlandii, Cyprze, dwóch z sześciu kantonów Szwaj-

${ }^{14}$ R. Czekalski, Rys historyczny lekcji religii katolickiej w Polsce, „Studia Katechetyczne” 7 (2010), s. 122-123; L. Adamczuk, Nauczanie religii w Polsce..., dz. cyt., s. 245; S. Skuza, Nauczanie religii w Polsce w świetle prawa państwowego po roku 1945, „Kolekcja Communio” 8(1993), s. 256.

15 S. Skuza, Nauczanie religii..., dz. cyt., s. 259.

16 Słowo biskupów polskich w związku z powrotem katechezy do szkół, w: Listy Pasterskie Episkopatu Polski 1945-2000, red. P. Libera, A. Rybicki, S. Łącki, cz. 2, Wydawnictwo Michalineum, Marki 2003, s. 1655-1657.

${ }^{17}$ M. Koseła, dz. cyt., s. 100.

${ }^{18}$ Zob. T. Panuś, Dwadzieścia lat minęto - o blaskach i cieniach katechezy w szkolnej rzeczywistości, „Sympozjum” 2(2011), s. 10-16.

${ }_{19}$ M. Kinal, Nauczanie religii w polskich szkołach w XX i XXI wieku, „Młoda Humanistyka" 2(2016), s. 5-6; http://www.humanistyka.com/index.php/MH/article/view/62/55 [dostęp 17.10.2017 r.]. 
carii. Obowiązkowość nauczania oznaczała, że rodzice, którzy nie chcieli, aby ich dzieci uczestniczyły w katechezie, byli zobowiązani do składania stosownych oświadczeń. W państwach europejskich takich jak: Włochy, Hiszpania, Portugalia, Szwecja, w większej części Szwajcarii, stosowano fakultatywny model nauczania religii w szkołach publicznych. Rodzice składali oświadczenia, że ich dzieci chcą brać udział w katechezie szkolnej. Model taki zastosowano również w Polsce ${ }^{20}$.

Sprawa nauczania religii w polskich szkołach została uregulowana w Konstytucji RP (art. 53, ust. 4). Zapisano w niej, że religia kościoła lub związku wyznaniowego, mającego uregulowaną sytuację prawną, może być przedmiotem nauczania w szkole przy poszanowaniu wolności sumienia i religii innych osób ${ }^{21}$. Natomiast w konkordacie państwo polskie zobowiązało się do organizowania nauczania religii w publicznych szkołach podstawowych i ponadpodstawowych oraz przedszkolach ${ }^{22}$.

Wprowadzenie nauczania religii do szkół stawiało przed Kościołem katolickim wyzwanie polegające przede wszystkim na konieczności zwiększenia liczby katechetów. Zajęcia miały odbywać się w wymiarze dwóch godzin lekcyjnych tygodniowo i mogły być prowadzone tylko przez osoby posiadające skierowanie od biskupa diecezjalnego ${ }^{23}$.

Według danych kościelnych, w roku 1992 katechizację szkolną prowadziło 29,9 tys. nauczycieli religii: księża diecezjalni i zakonnicy $(51,0 \%)$, katecheci świeccy $(36,8 \%)$, siostry zakonne $(12,2 \%)^{24}$. Niemal dwie dekady później (w 2009 r.) w polskich szkołach katechizowało 33,5 tys. katechetów. Najlicz-

${ }^{20}$ Z. Nosowski, Lekcje religii w szkołach publicznych państw europejskich, w: Szkoła czy parafia? Nauka religii $w$ szkole $w$ świetle badań socjologicznych, red. K. Kiciński, K. Koseła, W. Pawlik, Zakład Wydawniczy Nomos, Kraków 1995, s. 11-12; Ł. Kasper, A. Wojtas, Nauczanie religii w szkole - zgodne z konstytucją $i$ europejskimi standardami; http://www.katecheza.episkopat.pl/index.php/menu/nauczanie-religii-w-szkole/dokumenty-koscielne/104-nauczanie-religii-w-szkole-zgodne-z-konstytucja-i-europejskimi-standardami-2016 [dostęp 5.10.2017 r.].

${ }^{21}$ Konstytucja Rzeczpospolitej Polskiej z 2 kwietnia 1997 r., art. 53, ust. 4, (Dz.U. 1997 nr 78 poz. 483); http://prawo.sejm.gov.pl/isap.nsf/download.xsp/WDU19970780483/U/D19970483Lj. pdf [dostęp 24.11.2017 r.]. Zob. M. Pisarek, Obecność nauczania religii w publicznym systemie oświaty w świetle obowiazujacego prawa, Wydawnictwo i Drukarnia Diecezji Rzeszowskiej, Rzeszów 2013, s. 84.

${ }^{22}$ Konkordat między Stolicą Apostolską i Rzecząpospolitą Polską, podpisany w Warszawie dnia 28 lipca 1993 r., art 12, ust. 1-4 (Dz.U. 1998 nr 51 poz. 318); http://prawo.sejm.gov.pl/isap.nsf/ DocDetails.xsp?id=WDU19980510318 [dostęp 20.11.2017 r.]. Zob. M. Pisarek, dz. cyt., s. 101.

${ }^{23}$ Rozporządzenie Ministra Edukacji Narodowej z dnia 14 kwietnia 1992 r. w sprawie warunków i sposobu organizowania nauki religii w szkołach publicznych, par. 5. p. 1 oraz par. 8 p. 1. (Dz.U. $1992 \mathrm{nr} 36$ poz. 155); http://prawo.sejm.gov.pl/isap.nsf/DocDetails.xsp?id=WDU19920360155 [dostęp 19.11.2017 r.]. Zob. J. Szpet, Vademecum katechety, Księgarnia Świętego Wojciecha, Poznań 2000, s. 7.

${ }^{24}$ L. Adamczuk, Nauczanie religii w Polsce..., dz. cyt., s. 250. 
niej reprezentowani byli katecheci świeccy - 18,3 tys., stanowiący ponad połowę wszystkich nauczycieli religii (54,6\%). Zaangażowanie katechetyczne osób świeckich było silnie zróżnicowane zależnie od diecezji. Najniższy odsetek katechetów świeckich nauczał religii w diecezjach przemyskiej, rzeszowskiej i tarnowskiej (nie przekraczał 30\%), natomiast największy w diecezjach gnieźnieńskiej i wrocławskiej (przekraczał 70\%). Drugą pod względem liczebności kategorią nauczycieli religii byli kapłani diecezjalni i zakonni (37,6\%). W sumie religii nauczało 12,6 tys. księży diecezjalnych i zakonników. Ponadto w katechezę szkolną zaangażowanych było 2,6 tys. sióstr zakonnych $(7,8 \%)^{25}$.

Poważnym mankamentem nauczania religii w szkole było stopniowe powierzanie tego zadania osobom świeckim, przy równoczesnym rezygnowaniu przez księży z obowiązku katechizowania. W latach 1972-2009 dwukrotnie zmniejszył się odsetek kapłanów zaangażowanych w katechizację szkolną (z 78,1\% do $37,6 \%)$. W tym samym czasie nastąpił dynamiczny wzrost liczby katechetów świeckich (z 7,9\% do 54,6\%). Zmiany w strukturze kadry nauczającej religii nie wynikały z niedoboru księży, gdyż w Polsce nie występował kryzys powołań kapłańskich. Dla przykładu, w roku 2009 w katechizację szkolną formującą młode pokolenie zaangażowanych było 12,6 tys. księży diecezjalnych i zakonników, stanowiących około dwóch piątych ogólnej liczby duchownych. Pozostali księża nie byli zaangażowani w katechezę szkolną ${ }^{26}$. Zjawisko słabnącego zaangażowania księży w nauczanie religii w szkole jest niepokojącym symptomem. Można próbować go wytłumaczyć dobrymi chęciami duchowieństwa, które, powierzając katolikom świeckim obowiązki katechetyczne w szkole, stara się rozbudzić u nich większą aktywność apostolską. Wydaje się jednak, że działania, które sprawdzają się w krajach misyjnych, gdzie brakuje księży, nie znajdują uzasadnienia i zrozumienia w warunkach polskich.

Według danych z roku 2014, katecheci świeccy nadal stanowili większość ogółu nauczycieli religii w Polsce (56,1\%). Drugą pod względem liczebności kategorią byli księża diecezjalni i zakonni (36,1\%), najrzadziej w szkołach uczyły siostry zakonne (7,8\%). Wskaźniki te były bardzo zbliżone do danych z 2009 roku. Odnotowano jedynie niewielki wzrost odsetka (o 2,0\%) katechetów świeckich, przy zmniejszeniu o taką samą wartość wskaźnika księży. Odsetek sióstr zakonnych pozostał na niezmienionym poziomie $(7,8 \%)^{27}$.

25 J. Jaroń, Szkolnictwo katolickie i nauka religii, w: Kościół katolicki w Polsce 1991-2011. Rocznik statystyczny, Instytut Statystyki Kościoła Katolickiego SAC, Główny Urząd Statystyczny, Warszawa 2014, s. 233-334.

${ }^{26}$ Zob. E. Jarmoch, K. Rosa, Religia w szkołach..., dz. cyt., s. 257; E. Jarmoch, Księża diecezjalni, [w:] Kościół katolicki w Polsce 1991-2011. Rocznik statystyczny, Instytut Statystyki Kościoła Katolickiego SAC, Główny Urząd Statystyczny, Warszawa 2014, s. 94.

${ }^{27}$ S. Nowotny, Nauczanie religii w Polskich szkołach w świetle badań empirycznych, s. 2: http:// www.iskk.pl/images/stories/Instytut/dane/nowotny_prezentacja_28.08.15.pdf (dostęp 26.10.2017 r.). 
Zmiana proporcji między uczącymi religii duchownymi i świeckimi, na niekorzyść partycypacji księży w prowadzeniu zajęć, przekładała się na jakość katechezy w szkole oraz na jej krytyczne oceny. Uczniowie i rodzice oceniający nauczycieli religii, najwięcej krytycznych uwag wyrażali pod adresem katechetów świeckich. Najczęściej podnoszono brak kompetencji oraz niezrozumienie istoty katechezy. Uczniowie i rodzice twierdzili, że wielu katechetów świeckich nie rozumie religijnej specyfiki katechezy i sprowadza ją do roli zwykłego przedmiotu szkolnego. Część z nich nie posiada odpowiednich kwalifikacji. Ponadto wielu katechetów świeckich koncentruje się tylko na przekazywaniu wiedzy, zaniedbując funkcje wychowawcze. Nie są też oni - zdaniem respondentów - w swoim życiu autentycznymi świadkami nauki, którą głoszą ${ }^{28}$.

Rezygnowanie przez księży z nauczania religii w szkołach było elementem procesu niekorzystnego dla ewangelizacyjnej działalności Kościoła, polegającego na osłabianiu więzi katechezy z parafią, a nawet całkowitego wyprowadzania katechezy z parafii do szkół. W niektórych parafiach w pełni podzielano założenie, że szkoła nigdy nie zastąpi i nie wyręczy parafii w procesie katechizacji. Rezygnacja z katechezy parafialnej opierała się na błędnym przekonaniu, że zastąpi ją katecheza w szkole.

Doświadczenie życiowe szybko pokazało, że nauczanie religii w szkole nie jest w stanie zrealizować wszystkich podstawowych zadań katechezy, a zwłaszcza wychowania w wierze i wtajemniczenia chrześcijańskiego. Parafia nadal musi być środowiskiem, w którym następuje pogłębienie religijnej formacji młodych ludzi przez życie sakramentalne. Katecheza parafialna umożliwia młodym ludziom styczność z kapłanami pracującymi w parafii, wzmacnia więź ze społecznością parafialną, a także aktywizuje uczniów i motywuje ich do większego angażowania się w sprawy parafialne między innymi przez partycypowanie w działalności organizacji czy ruchów religijnych. Nauczanie religii na terenie szkoły spełnia wyznaczone mu zadania dopiero w łączności z katechizacją parafialną29. Szkolne nauczanie religii potrzebuje katechezy parafialnej, a katecheza parafialna potrzebuje nauki religii w szkole. Obie formy katechezy nawzajem się dopełniają i uzupełniają ${ }^{30}$. Na konieczność podtrzymywania silnego związku między parafią a nauczaniem religii w szkole zwraca uwagę Andrzej Potocki. Duchowny, który w swoich publikacjach sporo miejsca poświęcił problematyce szkolnej katechezy, przypomina, że przeniesiona z parafii na teren szkoły katecheza nie przestała być parafialną katechezą, a parafia powinna nadal pozostawać

28 J. Baniak, Katecheza szkolna w opiniach i ocenach młodzieży i rodziców, „Poznańskie Studia Teologiczne", 9(2000), s. 248-250.

29 A. Potocki, Parafia - podmiotem i miejscem katechezy, „Perspectiva. Legnickie Studia Teologiczno-Historyczne” 5(2006) nr 2, s. 84, 99. Zob. T. Panuś, dz. cyt., s. 23.

${ }^{30}$ W. Kujawin, Parafialne duszpasterstwo katechetyczne w optyce Magisterium Kościoła, „Łódzkie Studia Teologiczne” 3(2014), s. 33. 
jej krzewicielką i inspiratorką ${ }^{31}$. Nauka religii w szkole nie może zrealizować wszystkich zadań katechezy, gdyż nie jest równoznaczna z pogłębianiem formacji religijnej młodych ludzi. W katechizacji młodzieży „uprzywilejowaną rolę wypada przypisać parafii, a nie szkole" ${ }^{\prime 2}$. Dla procesu wychowawczego i edukacyjnego najlepszym rozwiązaniem jest sytuacja, gdy katecheta zna nie tylko szkołę i parafię, ale również naturalne środowiska wychowujące jego uczniów (rodzinę, grupę rówieśniczą, sąsiedztwo) ${ }^{33}$.

\section{Nauczanie religii w szkole w opinii Polaków}

Istotne znaczenie dla ustalenia, na ile nauczanie religii w szkole jest sukcesem duszpasterskim Kościoła katolickiego, a na ile jego porażką, mają oceny i opinie Polaków, wśród których zdecydowana większość, tj. około 90\% badanych, deklaruje się jako wierzący katolicy. Szczególnie ważnym wskaźnikiem są opinie uczniów dotyczące jakości katechezy szkolnej, a także frekwencja młodych ludzi na zajęciach.

Społeczne poparcie dla nauczania religii w szkołach

We wrześniu 1990 roku, a więc bezpośrednio po wprowadzeniu nauczania religii do szkół, 37\% badanych przez OBOP Polaków opowiadało się za religią jako przedmiotem nieobowiązkowym w szkołach, a $22 \%$ respondentów popierało szkolne nauczanie religii w ramach zajęć obowiązkowych. Za pozostawieniem katechezy w punktach katechetycznych było $39 \%$ badanych. Skumulowany odsetek respondentów wskazujących nauczanie religii jako przedmiot obowiązkowy i nieobowiązkowy w szkole państwowej był większy od odsetka osób opowiadających się za katechezą w punktach katechetycznych. Respondenci popierający nauczanie religii w szkole najczęściej byli przekonani, że przyczynia się ono do wzrostu akceptacji norm moralnych w społeczeństwie polskim ${ }^{34}$.

Powrót katechizacji do szkół spotkał się z przychylnymi reakcjami społeczeństwa. We wrześniu 1990 roku decyzję o wprowadzeniu nauczania religii do szkół badani przez CBOS dorośli Polacy przyjęli z radością (33\%) oraz zadowoleniem (28\%). W sumie $61 \%$ badanych pozytywnie oceniło przywrócenie

${ }^{31}$ A. Potocki, Wychowanie religijne w polskich przemianach. Studium socjologiczno-pastoralne, Wydawnictwo UKSW, Warszawa 2007, s. 254.

32 A. Potocki, O Kościele także socjologicznie, Wydawnictwo Naukowe PWN, Warszawa 2017, s. 589.

33 A. Potocki, Wychowanie religijne w polskich przemianach..., dz. cyt., s. 270.

${ }^{34}$ A. Brochwicz-Lewińska, Opinie o wprowadzaniu religii do szkót. Komunikat z badań, OBOP, 1990, s. 1-3; http://tnsglobal.pl/archiv_files/37_579_90.pdf [dostęp 17.10.2017 r.]. 
katechezy do szkół. Obojętność wobec tego faktu zadeklarowało $21 \%$ respondentów, natomiast niezadowolonych było $11 \%$. Tylko $2 \%$ wyrażało oburzenie $\mathrm{z}$ powodu decyzji ministra edukacji, umożliwiającej nauczanie religii $\mathrm{w}$ szkołach $^{35}$. Akceptację dla uczestnictwa w katechezie realizowanej w szkole wyrażała większość badanych uczniów ostatnich klas szkół ponadpodstawowych. Według badań CBOS, za nauką religii w salach szkolnych w roku 1991 opowiedziało się $52 \%$ badanych uczniów, rok później było to już 65\% respondentów. Natomiast nauczanie religii w punktach katechetycznych popierało odpowiednio 38\% i 33\% młodych ludzi ${ }^{36}$.

Większość Polaków akceptuje nauczanie religii w szkołach. Badania zrealizowane przez CBOS w latach 1991-2008 wskazywały na wzrastające poparcie dla katechezy w szkole. W roku 2007 prawie trzy czwarte ankietowanych (72\%) wyrażało aprobatę dla zajęć $\mathrm{z}$ religii $\mathrm{w}$ szkole, przeciwnego zdania był co czwarty badany (24\%). Wprawdzie w następnym roku poparcie to nieco zmalało (o $7 \%$ ), ale nadal było wyższe niż na początku lat dziewięćdziesiątych. Zwolennicy obecności katechezy w szkole przeważają we wszystkich badanych kategoriach społeczno-demograficznych. Badani Polacy zadeklarowali, że zdecydowanie bardziej cenią katechezę w szkole aniżeli lekcje z etyki. W 2008 roku większość badanych Polaków (56\%) zadeklarowała, że woli, aby ich dzieci w ramach zajęć szkolnych uczyły się religii, natomiast $16 \%$ wybrałoby dla swoich dzieci lekcje z etyki. Co piąty $(20 \%)$ badany chciałby posyłać swoje dzieci zarówno na religię, jak i etykę. Jedynie $2 \%$ respondentów nie wybrałoby żadnego z tych przedmiotów ${ }^{37}$.

Nauczanie religii w szkołach nie dzieli Polaków. Katecheza szkolna im nie przeszkadza, choć nie wszyscy ją popierają. W ciągu prawie dwóch dekad (19952013) zdecydowana większość Polaków deklarowała brak sprzeciwu wobec nauczania religii w szkole. W 2013 roku odpowiedź taką wybrało 82\% respondentów. W porównaniu z rokiem 1995 odsetek osób, które akceptowały nauczanie religii w szkole, zwiększył się o 3 punkty ${ }^{38}$.

Uczestnictwo młodzieży w katechezie

Polemiki na temat obecności katechezy w szkole nie miały większego wpływu na frekwencję uczniów na zajęciach. Powrót nauczania religii do szkół spotkał się niemal z powszechną aprobatą wśród uczniów i rodziców. W roku szkol-

${ }^{35}$ M. Koseła, Religia przy tablicy..., dz. cyt., s. 91.

36 Tamże, s. 115.

${ }^{37}$ M. Feliksiak, Religia $w$ systemie edukacji. Komunikat z badań, BS/136/2008, Warszawa 2008, s. 3; http://www.cbos.pl/SPISKOM.POL/2008/K_136_08.PDF [dostęp 11.10.2017 r.].

${ }_{38}$ M. Grabowska, Religia i Kościół w przestrzeni publicznej, BS?170/2013, Warszawa 2013, s. 2, 4; http://www.cbos.pl/SPISKOM.POL/2013/K_170_13.PDF [dostęp 14.10.2017 r.]. 
nym 1990/91 na 7,16 mln uczniów w katechezie szkolnej uczestniczyło 6,86 mln, co stanowiło $95,8 \%$ dzieci i młodzieży uczącej się w polskich szkołach. Bardzo wysoki odsetek uczniów biorących udział w katechezie odnotowano w szkołach podstawowych $(98,0 \%)$ i liceach ogólnokształcących $(92,2 \%)$, nieco niższy w szkołach niepełnych średnich zawodowych $(89,7 \%)$ i średnich szkołach zawodowych $(88,5 \%)$. Najniższy wskaźnik katechizacji był w szkołach artystycznych I stopnia $(51,0 \%)$, ale nie miał on większego wpływu na ogólny odsetek katechizowanych, gdyż w szkołach tych uczyło się ogółem 12,1 tys. młodzieży ${ }^{39}$. Najwięcej uczniów szkół podstawowych i ponadpodstawowych uczęszczało na lekcje religii w województwie tarnowskim $(99,3 \%)$, najmniej w województwie warszawskim (90,4\%). Na uwagę zasługuje fakt, iż katecheza szkolna spotkała się z pełną akceptacją rodziców dzieci szkół podstawowych, w miastach w nauczaniu religii brało udział 97,3\% dzieci, natomiast na wsi 99,3\% ${ }^{40}$.

Pomimo emocjonalnych dyskusji towarzyszących nauczaniu religii w szkole zdecydowana większość młodzieży uczestniczy w katechezie. Z badań socjologicznych wynika, iż uczniowie szkół średnich i zasadniczych zawodowych są zainteresowani nieobowiązkowym udziałem w katechezie szkolnej. Młodzi ludzie deklarują niemal powszechnie, że uczęszczają na lekcje religii w szkole.

Tabela 1. Udział uczniów w lekcjach religii (\%)

\begin{tabular}{|l|c|c|c|c|c|c|c|c|c|c|}
\hline $\begin{array}{l}\text { Czy uczęszczasz } \\
\text { na lekcje religii } \\
\text { w szkole? }\end{array}$ & 1991 & 1992 & 1994 & 1996 & 1998 & 2003 & 2008 & 2010 & 2013 & 2016 \\
\hline Tak & 81 & 85 & 88 & 84 & 89 & 90 & 91 & 93 & 89 & 75 \\
\hline Nie & 19 & 15 & 11 & 16 & 11 & 9 & 9 & 7 & 11 & 25 \\
\hline
\end{tabular}

W okresie 1991-1998 badania realizowało Centrum Badania Opinii Społecznej, w latach 20032016 badania przeprowadziło Krajowe Biuro ds. Przeciwdziałania Narkomanii

Źródło: M. Gwiazda, Religia w szkole - uczestnictwo i ocena, [w:] Młodzież 2016. Raport z badań, Centrum Badania Opinii Społecznej, Krajowe Biuro ds. Przeciwdziałania Narkomanii, Warszawa 2016, Młodzież 2016, s. 141.

$\mathrm{Z}$ autodeklaracji uczniów wynika, iż w pierwszym roku nauczania religii w szkole (1990/91) na zajęcia uczęszczało ośmiu na dziesięciu respondentów. W kolejnych latach frekwencja młodzieży na katechezie systematycznie wzrastała (z wyjątkiem 1996 r.). Tendencja wzrostowa utrzymała się do roku 2010. W katechezie szkolnej uczestniczyło wówczas 93\% badanych. Wyniki badań

${ }^{39}$ L. Adamczuk, Nauczanie religii w Polsce..., dz. cyt., s. 245.

${ }^{40}$ L. Adamczuk, Zasięg nauczania religii w szkołach polskich w 1991 r. w świetle danych statystycznych, [w:] Szkoła czy parafia. Nauka religii w szkole w świetle badań socjologicznych, red. K. Kiciński, K. Koseła, W. Pawlik, Zakład Wydawniczy Nomos, Kraków 1995, s. 17-21. 
zrealizowanych w kolejnych latach sygnalizowały odwrócenie trendu. W roku 2013 odsetek uczniów biorących udział w lekcjach religii spadł o cztery punkty w porównaniu do przedniego pomiaru, a na katechezę nie uczęszczał co dziewiąty badany (wynik identyczny jak w 1994 r.) W następnych trzech latach nasiliła się tendencja spadkowa (o 14\% w stosunku do 2013 r.).

W 2016 r. udział w lekcjach religii deklarowało trzy czwarte uczniów szkół ponadgimnazjalnych. Najczęściej na katechezę przychodzili uczniowie techników (83\%) i szkół zawodowych (76\%), natomiast najrzadziej licealiści (69\%). Jest to najsłabszy wynik od wprowadzenia nauczania religii do szkół publicznych. W porównaniu z rokiem 2013 największy spadek frekwencji na katechezie nastąpił w liceach ogólnokształcących (o 17\%), nieco mniejszy w technikach (o 13\%), najniższy spadek odnotowano w szkołach zawodowych (o 7\% ${ }^{41}$.

Obserwowane zmniejszanie się frekwencji uczniów na lekcjach religii jest powiązane z przemianami religijności i moralności młodego pokolenia. Wyniki badań socjologicznych informują, że zmniejsza się wskaźnik autodeklaracji wiary młodych ludzi oraz częstotliwość ich udziału w mszach, nabożeństwach czy spotkaniach religijnych ${ }^{42}$. Wielu uczniów postrzega partycypację w katechezie szkolnej jako udział w spotkaniach religijnych, na które w ogólne nie chcą przychodzić lub w których biorą udział nieregularnie. Uczestnictwo w praktykach religijnych jest traktowane przez młodzież jako jej sprawa prywatna, wyjęta spod kontroli rodziny czy otoczenia. Indywidualizacja dotyczy również wartości i norm moralnych propagowanych przez Kościół katolicki. Uczniowie coraz częściej traktują moralność kościelną relatywnie i selektywnie, wybierając z niej tylko to, co im w konkretnej sytuacji odpowiada ${ }^{43}$.

${ }^{41}$ R. Boguszewski, M. Feliksiak, M. Gwiazda, J. Kalka, Młodzież o sobie: wartości, obyczajowość, grupy odniesienia, [w:] Młodzież 2013. Opinie i diagnozy nr 28, red. M. Grabowska, J. Kalka, Centrum Badania Opinii Społecznej, Krajowe Biuro ds. Przeciwdziałania Narkomanii, Warszawa 2014, s. 123; M. Gwiazda, Religia w szkole - uczestnictwo i ocena, [w:] Młodzież 2016. Raport z badań, Centrum Badania Opinii Publicznej, Krajowe Biuro ds. Przeciwdziałania Narkomanii, Warszawa 2016, s. 141.

${ }^{42}$ Według badań GUS z 2015 roku, 72,6\% respondentów w wieku od 16 do 24 lat deklaruje się jako osoby wierzące. Pozostali uważają się za niezdecydowanych, obojętnych i niewierzących. W tej samej kategorii wiekowej 58,1\% badanych uczestniczy w praktykach religijnych co najmniej 2 razy w miesiącu. Pozostali wybrali odpowiedź: tylko z okazji świąt, jeszcze rzadziej, nigdy. Główny Urząd Statystyczny Departament Badań Społecznych i Warunków Życia, Urząd Statystyczny w Łodzi, Jakość życia w Polsce w 2015 r. Wyniki badania spójności społecznej, Zakład Wydawnictw Statystycznych, Warszawa 2017, s. 116-117. W latach 2010-2016 zwiększył się odsetek młodzieży szkół ponadgimnazjalnych, która deklaruje się jako niewierzący (o 6\%), a także wzrosła liczba uczniów w ogóle nieuczestniczących w praktykach religijnych (o 9\%). A. Głowacki, Religijność młodzieży, [w:] Młodzież 2016. Raport z badań, Centrum Badania Opinii Publicznej, Krajowe Biuro ds. Przeciwdziałania Narkomanii, Warszawa 2016, s. 131-133.

43 J. Mariański, Młodzież między tradycją i ponowoczesnością. Wartości moralne w świadomości maturzystów, Redakcja Wydawnictw Katolickiego Uniwersytetu Lubelskiego, Lublin 1995, s. 337; S. H. Zaręba, Dynamika świadomości religijno-moralnej młodzieży w warunkach przemian 
Zjawisko powolnego, ale permanentnego słabnięcia religijności młodych ludzi i oddzielania moralności od religii, wskazuje na wyraźne tendencje sekularyzacyjne $^{44}$. Sekularyzacja jest obecnie przez socjologów traktowana jako swoisty megatrend społeczno-kulturowy współczesnego świata. Za pomocą teorii sekularyzacji próbują oni wyjaśnić bieżące przemiany religijności. Sekularyzacja zmienia kształt i znaczenie religii w życiu prywatnym, dając człowiekowi możliwość indywidualnego wyboru norm, wartości czy prawd wiary ${ }^{45}$.

Postawy religijne polskiej młodzieży wpisują się w prawidłowości przemian religijności Europejczyków, która - według socjologa religii Janusza Mariańskiego -,,balansuje < dialektycznie> między sekularyzacją a desekularyzacją". Sekularyzacja i desekularyzacja przebiegają równolegle, z różnym nasileniem, zależnie od poszczególnych społeczeństw ${ }^{46}$. Balansowanie między sekularyzacją a desekularyzacją sprawia, że religijny pejzaż europejskich społeczeństw podlega głębokiej ewolucji i ambiwalencji. Można więc mówić nie tylko o kryzysie religii, ale również o jej odrodzeniu w ponowoczesnym świecie ${ }^{47}$.

Młodzież polska pozostaje w polu oddziaływania obu procesów społecznych. Z jednej strony ulega wpływom sekularyzacji, z drugiej jednak znajduje się w przestrzeni nowej ewangelizacji. W życiu młodych ludzi widoczne jest współistnienie sekularyzmu oraz procesu odradzania się religijności. Od siły tych procesów oraz ich wpływu na młode pokolenie w znacznym stopniu zależeć będzie sukces czy porażka katechezy szkolnej. Dotychczas większość polskiej młodzieży dostrzega w nauczaniu religii wartość, którą akceptuje i pozytywnie ocenia. Młodzi ludzie wybierają katechezę w szkole, mimo że przez niektóre wpływowe środowiska lewicowo-liberalne jest ona dyskredytowana i przedstawiana w mediach jako zagrożenie dla demokracji, świeckości szkoły i jej neutralności światopoglądowej. Sekularyzacja niekoniecznie oznacza odchodzenie młodych ludzi

ustrojowych w Polsce (1988-1998), Zakład Wydawnictw Statystycznych, Warszawa 2003, s. 274275; J. Mariański, Przemiany moralności polskich maturzystów w latach 1994-2009. Studium socjologiczne, Wydawnictwo KUL, Lublin 2011, s. 447-448; S. H. Zaręba, W kierunku jakiej religijności? Studia nad katolicyzmem polskiej młodzieży, Zakład Wydawnictw Statystycznych, Warszawa 2008, s. 505-507.

${ }^{44}$ J. Mariański, Malżeństwo i rodzina w świadomości młodzieży maturalnej. Stabilność i zmiana, Wydawnictwo Adam Marszałek, Toruń 2012, s. 93. Zob. A. Głowacki, Religijność młodzieży..., dz. cyt., s. 140.

${ }^{45}$ J. Mariański, Sekularyzacja jako megatrend społeczno-kulturowy, „Relacje Międzykulturowe. Kulturoznawcze Czasopismo Naukowe" 1(2017), s. 233.

46 J. Mariański, Sekularyzacja. Desekularyzacja. Nowa duchowość. Studium socjologiczne, Zakład Wydawniczy NOMOS, Kraków 2013, s. 23. Zjawiska religijne specyficzne dla współczesnych społeczeństw Janusz Mariański analizuje w ścisłym powiązaniu z bieżącymi przemianami społeczno-kulturowymi. Poszukuje trwałych kierunków przemian zjawisk religijnych w modernizującym i globalizującym się świecie, by wskazać trendy rozwojowe współczesnych religii i duchowości. Wyniki swoich badań przedstawił w książce: J. Mariański, Megatrendy religijne w społeczeństwach ponowoczesnych. Studium socjologiczne, Wydawnictwo Adam Marszałek, Torun 2016.

${ }^{47} \mathrm{~J}$. Mariański, Megatrendy religijne w społeczeństwach ponowoczesnych..., dz. cyt., s. 333-334. 
od religii, ponieważ może być przejawem zmiany jej charakteru i funkcji. Doraźne osłabienie wpływu Kościoła na religijność młodzieży nie wyklucza zmiany jego postrzegania w przyszłości ${ }^{48}$.

Uczestnictwo w nauczaniu religii związane jest ze stanem religijności młodzieży, a zwłaszcza z jej uczestnictwem w praktykach religijnych oraz z autodeklaracjami wiary. Najczęściej na katechezę szkolną przychodzą uczniowie, którzy regularnie uczestniczą $\mathrm{w}$ praktykach religijnych oraz deklarują się jako głęboko wierzący i wierzący. Wraz ze zmniejszaniem się częstotliwości udziału w praktykach religijnych i zwiększeniem się wątpliwości dotyczących wiary obniża się frekwencja na lekcjach religii. Na uwagę zasługuje fakt, że w 2016 roku na katechezę szkolną uczęszczała połowa uczniów w ogóle niepraktykujących (52\%) oraz ponad dwie piąte (44\%) młodych ludzi deklarujących się jako niewierzący ${ }^{49}$.

Zmienną, silnie różnicującą deklaracje dotyczące uczestnictwa w lekcjach religii, jest miejsce zamieszkania badanej młodzieży. W 2016 roku najczęściej na katechezę chodziła młodzież ze środowiska wiejskiego (85\%), natomiast najrzadziej uczniowie z największych, ponadstutysięcznych miast $(49 \%)^{50}$.

Badani uczniowie wskazują różne motywy skłaniające ich do uczestnictwa w katechezie szkolnej. Najczęściej młodzi ludzie przychodzą na lekcje religii, ponieważ odczuwają wewnętrzną potrzebę ugruntowania swojej wiary i pogłębienia wiedzy religijnej. Udział w katechezie traktują jako swój obowiązek wynikający z wiary w Boga. Inni uczniowie swoją frekwencję na lekcjach religii uzasadniają wychowaniem w rodzinie katolickiej i tradycją rodzinną. Jeszcze inni ujawniają swoje konformistyczne podejście do katechezy szkolnej. Twierdzą, że uczestniczą $\mathrm{w}$ nauczaniu religii, ponieważ nie chcą mieć w przyszłości kłopotów, wynikających z braku oceny z religii na świadectwie szkolnym. Część uczniów chce uniknąć napięć czy konfliktów w domu rodzinnym, ponieważ rodzice polecają im, aby chodzili na lekcje religii. Motywem partycypacji w katechezie szkolnej jest również unikanie zwracania na siebie uwagi, by nie wyróżniać się w klasie. Dlatego niektórzy uczniowie chodzą na zajęcia z religii, gdyż uczestniczy w nich cała klasa ${ }^{51}$.

Uczniowie nieuczęszczający na lekcje religii uzasadniają swoją absencję różnymi argumentami. Twierdzą, że są niewierzący lub przeciwni nauczaniu religii w szkole. Zazwyczaj mają negatywny stosunek do Kościoła i do wszystkiego,

48 J. Mariański, Religijność młodzieży polskiej w okresie przemian, „Zeszyty Naukowe KUL”, 2(2010), s. 40-41.

${ }^{49}$ M. Gwiazda, dz. cyt., s. 144-145.

${ }^{50}$ R. Boguszewski, M. Feliksiak, M. Gwiazda, J. Kalka, dz. cyt., s. 125; M. Gwiazda, dz. cyt., s. 143.

${ }^{51}$ A. Szwajkajzer, Młodzież o lekcjach religii w szkole, [w:] Szkoła czy parafia? Nauka religii w szkole w świetle badań socjologicznych, red. K. Kiciński, K. Koseła, W. Pawlik, Zakład Wydawniczy Nomos, Kraków 1995, s. 145-147. 
co się z nim wiąże. Nie odpowiada im sposób prowadzenia katechezy w szkole, uważają ją za przedmiot nudny. Nie są również zadowoleni z jakości nauczania tego przedmiotu. Ich zdaniem, wartość intelektualna i duchowa lekcji religii jest wątpliwa. Katecheza szkolna nie przygotowuje uczniów do samodzielnego i odpowiedzialnego życia chrześcijańskiego. Prowadzący zajęcia nie są otwarci na opinie i przekonania inaczej myślących i nie podejmują z nimi dyskusji ${ }^{52}$.

Ocena jakości nauczania religii w szkole

Istotne znaczenie dla określenia jakości nauczania religii w szkole mają oceny wyrażane przez zainteresowanych uczniów. W roku 2016 dwie piąte respondentów oceniało lekcje religii jako ciekawe i dlatego chętnie brało w nich udział, prawie tyle samo uczniów (38\%) twierdziło, że katecheza niczym szczególnym się nie wyróżnia i jest jak każda inna lekcja, natomiast niezadowolenie z zajęć deklarował nieco więcej niż co piąty uczeń (22\%). Porównanie wyników badań z lat 1992-2016 pokazuje, że w ocenach młodzieży odnoszących się do jakości nauczania katechezy w okresie 24 lat, wystąpiły jedynie nieznaczne zmiany.

Tabela 2. Ocena lekcji religii przez uczniów (\%)

\begin{tabular}{|l|c|c|c|c|c|}
\hline $\begin{array}{l}\text { Jeśli uczęszczasz na lekcje religii w szkole, jak } \\
\text { je oceniasz? }\end{array}$ & 1992 & 1998 & 2003 & 2013 & 2016 \\
\hline Są ciekawe - chodzę na nie z ochotą & 36 & 41 & 41 & 34 & 40 \\
\hline $\begin{array}{l}\text { Są jak każde inne lekcje - niczym szczególnym } \\
\text { się nie wyróżniają }\end{array}$ & 39 & 36 & 34 & 38 & 38 \\
\hline Są nudne, nic ważnego się na nich nie dzieje & 25 & 23 & 25 & 28 & 22 \\
\hline
\end{tabular}

Źródło: M. Gwiazda, Religia w szkole - uczestnictwo i ocena, [w:] Młodzież 2016. Raport z badań, Centrum Badania Opinii Społecznej, Krajowe Biuro ds. Przeciwdziałania Narkomanii, Warszawa 2016, s. 146; R. Boguszewski, M. Feliksiak, M. Gwiazda, J. Kalka, Młodzież o sobie: wartości, obyczajowość, grupy odniesienia, Młodzież 2013. Opinie i diagnozy nr 28, red. M. Grabowska, J. Kalka, Centrum Badania Opinii Społecznej, Krajowe Biuro ds. Przeciwdziałania Narkomanii, Warszawa 2014, s. 119-120; B. Badora, M. Gwiazda, J. Kalka, G. Świątkiewicz, Młodzież 2003. Opinie i diagnozy nr 2, Centrum Badania Opinii Społecznej, Krajowe Biuro ds. Przeciwdziałania Narkomanii, Warszawa 2004, s. 51; https:/ud.interia.pl/html/getattach,mid,71836,mpid,6,uid,107f055071e8ba65,min,0,nd,1,mimetype,application\%2Fpdf,/M\%C5\%82odzie\%C5\%BC_2003. pdf?f=M\%C5\%82odzie\%C5\%BC_2003.pdf [dostęp 24.11.2017 r.].

Nauczanie religii najlepiej oceniali uczniowie techników i zasadniczych szkół zawodowych, natomiast bardziej krytyczni byli uczniowie liceów ogólnokształcących. Najwyższy odsetek wśród uczniów negatywnie oceniających lekcje religii stanowiły osoby biorące udział w praktykach religijnych kilka razy

${ }^{52}$ A. Szwajkajzer, dz. cyt., s. 147. Zob. A. Potocki, Wychowanie religijne w polskich przemianach..., dz. cyt., s. 256-258. 
w roku, w ogóle w nich nieuczestniczące, niezdecydowane pod względem wiary oraz niewierzące ${ }^{53}$.

Stabilne w okresie ćwierćwiecza oceny dotyczące jakości nauczania religii w szkołach mogą być wynikiem realizowania przez katechetów jednakowych programów kształcenia oraz stosowania podobnych metod nauczania. Oceny dwóch piątych uczniów, deklarujących, że nauczanie religii wyróżnia się spośród innych przedmiotów i ich zaciekawia, jest istotnym atutem katechezy w szkole. Wskaźnika tego nie da się porównać z ocenami wystawianymi przez uczniów innym przedmiotom nauczanym w szkole ze względu na brak danych.

Większość badanych uczniów wystawiła pozytywną ocenę katechetom i ich pracy. Pozytywnie oceniono również poziom merytoryczny oraz dydaktyczny katechezy. Najczęściej uczniowie twierdzili, że katecheta jest starannie przygotowany i dobrze prowadzi zajęcia. Jednak część uczniów uważała, że katecheta nie jest przygotowany do zajęć i źle je realizuje, a także lekceważy katechezę i jej uczestników ${ }^{54}$. Badani doceniali wartość katechezy w wychowaniu oraz formacji religijno-moralnej młodego pokolenia. Twierdzili, że katecheza z różną częstotliwością pomaga młodzieży w zrozumieniu problemów religii i moralności, uczy modlitwy i zachęca do praktyk religijnych, a także zapoznaje z życiem parafii ${ }^{55}$.

Osobom uczestniczącym w katechezie szkolnej podobał się sposób jej prowadzenia i metody przekazywania treści, a także możliwość uczestniczenia w twórczej dyskusji, podczas której mogą wyrazić swoje opinie oraz otrzymać wyjaśnienia ze strony prowadzącego. Twierdzili, że na katechezie w szkole jest miła i przyjemna atmosfera, umożliwiająca odprężenie oraz swobodny i luźny udział w zajęciach. Pozytywnie oceniono osoby prowadzące zajęcia, które wykazują się empatią ${ }^{56}$. Natomiast krytyka katechezy szkolnej dotyczyła najczęściej mało interesującego sposobu jej prowadzenia, nieodpowiedniego podejścia do problemów życiowych młodzieży, koncentrowania się przez prowadzących na tematach kościelnych i teologicznych oraz braku dyscypliny podczas zajęćs Młodzi ludzie niepochlebnie wyrażający się o nauczaniu religii w szkole wskazywali, że katecheza nie ma związku z ich życiem, nie przygotowuje do życia w rodzinie, a także nie oddziałuje na religijność i moralność młodego pokolenia lub wpływa na nie w stopniu bardzo ograniczonym ${ }^{58}$.

\footnotetext{
${ }^{53}$ M. Gwiazda, dz. cyt., s. 146-147.

54 J. Baniak, dz. cyt., s. 246-247.

55 Tamże, s. 251-256.

56 A. Szwajkajzer, dz. cyt., s. 153-154.

57 Tamże, s. 154-155.

58 J. Baniak, dz. cyt., s. 246-247, 251.
} 


\section{Podsumowanie}

Społeczeństwo polskie zaakceptowało powrót nauczania religii do szkół. Większość badanych Polaków, w tym uczniów i rodziców, wyraża aprobatę obecności katechezy w szkole, gdyż dostrzega w niej wiele pozytywnych elementów, a zwłaszcza pomoc rodzinie w moralno-religijnym wychowaniu młodego pokolenia. Nauczanie religii w szkołach spowodowało upowszechnienie katechizacji w skali wcześniej niespotykanej, ponieważ w zajęciach w sposób systematyczny uczestniczy zdecydowana większość dzieci i młodzieży. Badania socjologiczne nie potwierdzają obaw, że nauczanie religii w szkole generuje niepokoje, konflikty i podziały w społecznościach szkolnych. Najczęściej w katechezie szkolnej uczestniczą uczniowie wierzący i regularnie praktykujący, zamieszkujący wioski i nieduże miasta, najrzadziej młodzież z dużych miast. Zainteresowanie katechezą w szkole potwierdza fakt, że przychodzi na nią prawie połowa uczniów niepraktykujących i niewierzących. W roku 2016 większość badanych przez CBOS uczniów (67\%) stwierdziła, że najlepszą formą nauczania religii są zajęcia w szkole.

Dla młodych ludzi, którzy nie uczestniczą w praktykach religijnych, a poszukują systemu wartości, z którym chcieliby się w życiu identyfikować, nauczanie religii w szkole staje się okazją do spotkania z Kościołem i jego nauczaniem. Wielu młodych, którzy z powodu wątpliwości w wierze, nie praktykują i nie mają styczności z parafią, dzięki udziałowi w katechezie szkolnej utrzymuje więź z Kościołem. Dla części z nich spotkanie z religią w szkole jest wartością, do której powracają po latach zwątpienia, buntu, czy poszukiwania sensu swojego życia. Katecheza w szkole jest szczególnie cennym źródłem socjalizacji moralnej i religijnej dla uczniów, których rodzice przerzucają na katechetów swój obowiązek wychowania dzieci w duchu religijnym. W takiej sytuacji jedynie katecheza szkolna daje młodym ludziom możliwość otrzymania oraz pogłębiania formacji religijnej i moralnej.

Stopniowy spadek religijności i moralności młodego pokolenia w Polsce stawia niewątpliwie pod znakiem zapytania skuteczność katechezy w szkole. Trend ten można interpretować jako porażkę powszechnego nauczania religii w szkole, które nie jest w stanie zatrzymać procesu sekularyzacji i indywidualizacji postaw młodzieży. Wydaje się jednak, że katecheza w polskich szkołach, jeśli nawet nie powstrzymuje skutecznie tychże procesów, to jednak znacznie ją wyhamowuje i oddziałuje stabilizująco na postawy i zachowania religijne młodych Polaków.

Doświadczenie życiowe pokazuje, że nauczanie religii jest powiązane z procesem laicyzacji. We Francji laicyzacja państwa i sekularyzacja społeczeństwa rozpoczęła się od szkoły, z której usunięto nauczanie religii. Z grona osób uczących w szkołach publicznych wykluczono duchownych, którym zabroniono prowadzenia zajęć. Nauczanie „moralności religijnej” zastąpiono nauczaniem „wie- 
dzy obywatelskiej i moralności”. Na wniosek rodziców lekcje religii mogły być organizowane tylko poza szkołami publicznymi. W wyniku realizacji koncepcji świeckiej szkoły oraz innych działań ograniczających oddziaływanie religii na społeczeństwo, Francja stała się w stosunkowo krótkim czasie jednym z najbardziej zlaicyzowanych państw europejskich ${ }^{59}$.

Nie ulega wątpliwości, iż w Polsce proces sekularyzacji młodego pokolenia byłby o wiele bardziej zaawansowany, gdyby nie praca około 30 tysięcy katechetów ewangelizujących w szkołach. Powszechny, ale nieobowiązkowy dostęp do katechezy w szkole, bardzo wysoka frekwencja uczniów na lekcjach religii oraz pozytywne opinie większości badanych Polaków na temat katechizacji w szkołach są niewątpliwie sukcesem tej formy działalności ewangelizacyjnej polskiego Kościoła.

Katecheza w szkole jest dla Kościoła wielką wartością, a także najpopularniejszym instrumentem oddziaływania ewangelizacyjnego na młode pokolenie. Wydaje się jednak, że wartość ta jest w wielu przypadkach niedoceniana przez tych ludzi Kościoła, którzy nie starają się wykorzystać możliwości duszpasterskich, jakie daje im katechizacja dzieci i młodzieży w szkole. Niekorzystnym zjawiskiem jest niewątpliwie zmniejszająca się partycypacja duchownych w katechizacji szkolnej.

Symptomem, wskazującym na niepomyślne zmiany w procesie nauczania religii staje się malejąca od kilku lat frekwencja na katechezie w szkole. Zjawisko to jest zapewne powiązane z obniżającym się wśród młodzieży poziomem deklarowanej wiary oraz spadkiem systematycznego udziału w praktykach religijnych. Młodzi ludzie, mieszkający na wsi i w małych miastach, którzy wcześniej regularnie uczestniczyli w praktykach religijnych i w katechezie szkolnej, upodabniają się do swoich rówieśników z większych miast, przejawiających mniejsze zainteresowanie wiarą i sprawami religijnymi.

Wpływ na spadek frekwencji młodzieży na katechezie szkolnej i na słabsze oceny jakości nauczania religii ma zmniejszające się wśród kapłanów zainteresowanie katechizacją szkolną oraz przenoszenie ciężaru odpowiedzialności za organizację katechezy z parafii na szkołę i na osoby świeckie. Rezygnowanie przez księży z trudnego obowiązku katechizowania w szkole i powierzania go osobom świeckim nie jest pozytywnie oceniane przez uczniów i rodziców. Ponadto zmniejszająca się partycypacja kapłanów w nauczaniu religii przyczynia się do osłabienia więzi uczniów ze swoją parafią i Kościołem.

Pomimo wymienionych powyżej mankamentów, nauczanie religii $\mathrm{w}$ polskich szkołach należy uznać za dopełnienie katechezy parafialnej, a także za dużą wartość w misji ewangelizacyjnej Kościoła. Wartość ta może jednak ulegać de-

${ }^{59}$ K. Orzeszyna, Świeckość szkoły a nauczanie religii we Francji, „Roczniki Nauk Prawnych” 2(2004), s. 5-12. 
waluacji, jeśli księża nadal będą rezygnować z katechezy w szkole, traktując ją jako niewdzięczny czy niechciany obowiązek, od którego z błahych powodów się uwalniają, przekazując katechizację osobom świeckim.

\section{Religious Education in Polish schools - a success or a failure?}

\section{Summary}

Religious Education was reintroduced to state Polish schools in September 1990. The participation is not obligatory and it depends on parents and pupils. Sociological studies show that Religious Education has far more supporters than opponents which, undoubtedly, is the pastoral success of the Catholic Church. Despite the fact that in the last few years the attendance at RE was dropping, the vast majority of pupils still participate in it. Young people assess the quality of RE in a positive way. Some of them think that RE is interesting and they participate in it willingly. Others are of the opinion that RE is no different from other subjects.

For the Catholic Church Religious Education is an important pastoral task. Therefore, it undertakes activities in order to provide qualified RE teachers. The drawback of this effort is, undoubtedly, the fact that the catechization at school is done by laypeople with the simultaneous pullback of priests. Both pupils and parents are of the opinion that such actions not only impair the quality of $\mathrm{RE}$ teaching and lead to poor participation but also damage the relation between young people and parishes. In times when the level of religiosity and morality is falling, the Church should intensify its effort to stop the process of secularization of young generation and strengthen or even rebuild the relation between young people with local Church communities by providing effective RE teaching.

\section{Keywords}

religious education, catechesis, school, perish, evangelization, children and youth, faith, religiosity

\section{Słowa kluczowe}

nauczanie religii, katecheza, szkoła, parafia, ewangelizacja, dzieci i młodzież, wiara, religijność

\section{Bibliografia}

Adamczuk L., Nauczanie religii w Polsce 1945-1999, w: Kościót i religijność Polaków 1945-1999, red. W. Zdaniewicz, T. Zembrzuski, Instytut Statystyki Kościoła Katolickiego SAC, Warszawa 2000, s. 223-251.

Adamczuk L., Zasięg nauczania religii w szkołach polskich w 1991 r. w świetle danych statystycznych, w: Szkoła czy parafia. Nauka religii $w$ szkole $w$ świetle badań socjologicznych, red. K. Kiciński, K. Koseła, W. Pawlik, Zakład Wydawniczy Nomos, Kraków 1995, s. 15-24.

Baniak J., Katecheza szkolna w opiniach i ocenach młodzieży i rodziców, „Poznańskie Studia Teologiczne "9(2000), s. 237-259.

Boguszewski R., Feliksiak M., Gwiazda M., Kalka J., Młodzież o sobie: wartości, obyczajowość, grupy odniesienia, [w:] Młodzież 2013. Opinie i diagnozy nr 28, red. M. Grabowska, J. Kalka, Centrum Badania Opinii Społecznej, Krajowe Biuro ds. Przeciwdziałania Narkomanii, Warszawa 2014, s. 112-159. 
Czekalski R., Rys historyczny lekcji religii katolickiej w Polsce, „Studia Katechetyczne” 7(2010), s. 99-125.

Dokument 32: Analiza postaw członków PZPR wobec religii opracowana w Akademii Nauk Społecznych PZPR (lipiec 1985 r.), [w:] Tajne dokumenty Państwo - Kościót 1980-1989, Wydawnictwo Aneks \& Polityka, Londyn - Warszawa 1993, s. 430-438.

Domingues M.P., Parafia jako miejsce ewangelizacji, „Kolekcja Communio” 8(1993), s. 299-312.

Głowacki A., Religijność młodzieży, [w:] Młodzież 2016. Raport z badań, Centrum Badania Opinii Społecznej, Krajowe Biuro ds. Przeciwdziałania Narkomanii, Warszawa 2016, s. 130-140.

Główny Urząd Statystyczny Departament Badań Społecznych i Warunków Życia, Urząd Statystyczny w Łodzi, Jakość życia w Polsce w 2015 r. Wyniki badania spójności społecznej, Zakład Wydawnictw Statystycznych, Warszawa 2017.

Gwiazda M., Religia w szkole - uczestnictwo i ocena, [w:] Młodzież 2016. Raport z badań, Centrum Badania Opinii Społecznej, Krajowe Biuro ds. Przeciwdziałania Narkomanii, Warszawa 2016, s. 141-152.

Jan Paweł II, Adhortacja apostolska o katechizacji w naszych czasach (Catechesi tradendae), [w:] Adhortacje ojca świętego Jana Pawła II, t. 1, Wydawnictwo św. Stanisława B.M. Archidiecezji Krakowskiej, Wydawnictwo M, Kraków 1996, s. 3-64.

Jan Paweł II, Posynodalna adhortacja Christifideles laici, Wydawnictwo Wrocławskiej Księgarni Archidiecezjalnej, Wrocław 1990.

Jarmoch E., Księża diecezjalni, w: Kościół katolicki w Polsce 1991-2011. Rocznik statystyczny, Instytut Statystyki Kościoła Katolickiego SAC, Główny Urząd Statystyczny, Warszawa 2014, s. 91-100.

Jarmoch E., Rosa K., Religia w szkołach i katechizacja, [w:] Kościót katolicki w Polsce. Rocznik statystyczny, red. L. Adamczuk, W. Zdaniewicz, Główny Urząd Statystyczny, Zakład Socjologii Religii SAC, Warszawa 1991, s. 252-264.

Jaroń J., Szkolnictwo katolickie i nauka religii, w: Kościół katolicki w Polsce 1991-2011. Rocznik statystyczny, Instytut Statystyki Kościoła Katolickiego SAC, Główny Urząd Statystyczny, Warszawa 2014, s. 231-234.

Katechizm Kościoła katolickiego, Wydawnictwo Pallottinum, Poznań 1994.

Komunikat 240 Konferencji Plenarnej Episkopatu Polski (Warszawa, 2 maja 1990 r.), [w:] Komunikaty Konferencji Episkopatu Polski 1945-2000, opr. J. Żaryn, Sekretariat Konferencji Episkopatu Polski, Pallottinum, Warszawa 2006, s. 352-354.

Konferencja Episkopatu Polski, Dyrektorium katechetyczne Kościoła katolickiego w Polsce, Warszawa 2001.

Kongregacja ds. Duchowieństwa, Dyrektorium ogólne o katechizacji, Pallottinum 1998.

Koseła K., Religia przy tablicy - postawy wobec lekcji religii w szkołach, [w:] Szkoła czy parafia? Nauka religii w szkole w świetle badań socjologicznych, red. K. Kiciński, K. Koseła, W. Pawlik, Zakład Wydawniczy Nomos, Kraków 1995, s. 88-121.

Kujawin W., Parafialne duszpasterstwo katechetyczne w optyce Magisterium Kościoła, „Łódzkie Studia Teologiczne" 3(2014), s. 25-37.

Mariański J., Matżeństwo i rodzina $w$ świadomości młodzieży maturalnej. Stabilność i zmiana, Wydawnictwo Adam Marszałek, Torun 2012.

Mariański J., Megatrendy religijne w społeczeństwach ponowoczesnych. Studium socjologiczne, Wydawnictwo Adam Marszałek, Torun 2016.

Mariański J., Młodziez między tradycją i ponowoczesnościa. Wartości moralne w świadomości maturzystów, Redakcja Wydawnictw Katolickiego Uniwersytetu Lubelskiego, Lublin 1995.

Mariański J., Przemiany moralności polskich maturzystów w latach 1994-2009. Studium socjologiczne, Wydawnictwo KUL, Lublin 2011.

Mariański J., Religijność młodzieży polskiej w okresie przemian, „Zeszyty Naukowe KUL”2(2010), s. 39-61. 
Mariański J., Sekularyzacja. Desekularyzacja. Nowa duchowość. Studium socjologiczne, Zakład Wydawniczy NOMOS, Kraków 2013.

Mariański J., Sekularyzacja jako megatrend społeczno-kulturowy, „Relacje Międzykulturowe. Kulturoznawcze Czasopismo Naukowe" 1(2017), s. 231-257.

List pasterski episkopatu Polski w sprawie powrotu katechizacji do szkoły polskiej, [w:] Listy Pasterskie Episkopatu Polski 1945-2000, red. P. Libera, A. Rybicki, S. Lącki, cz. 2, Wydawnictwo Michalineum, Marki 2003, s. 1649-1653.

Nosowski Z., Lekcje religii w szkołach publicznych państw europejskich, [w:] Szkoła czy parafia? Nauka religii w szkole $w$ świetle badań socjologicznych, red. K. Kiciński, K. Koseła, W. Pawlik, Zakład Wydawniczy Nomos, Kraków 1995, s. 11-13.

Orzeszyna K., Świeckość szkoty a nauczanie religii we Francji, „Roczniki Nauk Prawnych” 2(2004), s. 5-21.

Panuś T., Dwadzieścia lat minęto - o blaskach i cieniach katechezy w szkolnej rzeczywistości, „Sympozjum” 2(2011), s. 9-26.

Pisarek M., Obecność nauczania religii w publicznym systemie oświaty w świetle obowiazujacego prawa, Wydawnictwo i Drukarnia Diecezji Rzeszowskiej, Rzeszów 2013.

Potocki A., O Kościele także socjologicznie, Wydawnictwo Naukowe PWN, Warszawa 2017.

Potocki A., Parafia - podmiotem i miejscem katechezy, „Perspectiva. Legnickie Studia Teologiczno-Historyczne" 5(2006) nr 2, s. 84-100.

Potocki A., Wychowanie religijne w polskich przemianach. Studium socjologiczno-pastoralne, Wydawnictwo UKSW, Warszawa 2007.

Skuza S., Nauczanie religii w Polsce w świetle prawa państwowego po roku 1945, „Kolekcja Communio" 8(1993), s. 203-265.

Słowo biskupów polskich w związku z powrotem katechezy do szkół, [w:] Listy Pasterskie Episkopatu Polski 1945-2000, red. P. Libera, A. Rybicki, S. Łącki, cz. 2, Wydawnictwo Michalineum, Marki 2003, s. 1654-1657.

Szawiel T., Religijność i jej korelaty, [w:] Ciagłość i zmiana tradycji kulturowej, red. S. Nowak, Państwowe Wydawnictwo Naukowe, Warszawa 1989, s. 232-262.

Szpet J., Vademecum katechety, Księgarnia Świętego Wojciecha, Poznań 2000.

Szwajkajzer A., Młodzież o lekcjach religii w szkole, [w:] Szkoła czy parafia? Nauka religii w szkole w świetle badań socjologicznych, red. K. Kiciński, K. Koseła, W. Pawlik, Zakład Wydawniczy Nomos, Kraków 1995, s. 141-160.

Tomasik P., Religia $w$ dialogu z edukacją. Studium na temat korelacji nauczania religii katolickiej z polska edukacją szkolna, Wydawnictwo Salezjańskie, Warszawa 2004.

Zaręba S.H., Dynamika świadomości religijno-moralnej młodzieży w warunkach przemian ustrojowych w Polsce (1988-1998), Zakład Wydawnictw Statystycznych, Warszawa 2003.

Zaręba S.H., W kierunku jakiej religijności? Studia nad katolicyzmem polskiej młodzieży, Zakład Wydawnictw Statystycznych, Warszawa 2008.

\section{Netografia}

Badora B., Gwiazda M., Kalka J., Świątkiewicz G., Młodzież 2003. Opinie i diagnozy nr 2, Centrum Badania Opinii Społecznej, Krajowe Biuro ds. Przeciwdziałania Narkomanii, Warszawa 2004; https:/ud.interia.pl/html/getattach,mid,71836,mpid,6,uid,107f055071e8ba65,min,0,nd,1,mimetype,application\%2Fpdf,/M\%C5\%82odzie\%C5\%BC_2003.pdf?f=M\%C5\%82odzie\%C5\%BC_2003.pdf [dostęp 24.11.2017 r.].

Brochwicz-Lewińska A., Opinie o wprowadzaniu religii do szkót. Komunikat z badań, OBOP, 1990; http://tnsglobal.pl/archiv_files/37_579_90.pdf [dostęp 17.10.2017 r.]. 
Feliksiak M., Religia w systemie edukacji. Komunikat z badań, BS/136/2008, Warszawa 2008; http://www.cbos.pl/SPISKOM.POL/2008/K_136_08.PDF [dostęp 11.10.2017 r.].

Grabowska M., Religia i Kościół w przestrzeni publicznej, BS?170/2013, Warszawa 2013; http:// www.cbos.pl/SPISKOM.POL/2013/K_170_13.PDF [dostęp 14.10.2017 r.].

Kasper Ł., Wojtas A., Nauczanie religii w szkole - zgodne z konstytucja i europejskimi standarda$m i$; http:/www.katecheza.episkopat.pl/index.php/menu/nauczanie-religii-w-szkole/dokumenty-koscielne/104-nauczanie-religii-w-szkole-zgodne-z-konstytucja-i-europejskimi-standardami-2016 [dostęp 5.10.2017 r.].

Kinal M., Nauczanie religii w polskich szkołach w XX i XXI wieku, „Młoda Humanistyka” 2(2016); http://www.humanistyka.com/index.php/MH/article/view/62/55 [dostęp 17.10.2017 r.].

Konkordat między Stolicą Apostolską i Rzecząpospolitą Polską, podpisany w Warszawie dnia 28 lipca 1993 r., art 12, ust. 1-4 (Dz.U. $1998 \mathrm{nr} 51$ poz. 318); http://prawo.sejm.gov.pl/isap.nsf/ DocDetails.xsp?id=WDU19980510318 [dostęp 20.11.2017 r.].

Konstytucja Rzeczpospolitej Polskiej z 2 kwietnia 1997 r., art. 53, ust. 4, (Dz.U. 1997 nr 78 poz.483; http://prawo.sejm.gov.pl/isap.nsf/download.xsp/WDU19970780483/U/D19970483Lj.pdf [dostęp 24.11.2017.

Nowotny S., Nauczanie religii w Polskich szkołach w świetle badań empirycznych; http://www.iskk. pl/images/stories/Instytut/dane/nowotny_prezentacja_28.08.15.pdf [dostęp 26.10.2017 r.].

Roporządzenie Ministra Edukacji Narodowej z dnia 14 kwietnia 1992 r. w sprawie warunków i sposobu organizowania nauki religii w szkołach publicznych, par. 5. p. 1 oraz par. 8 p. 1 . (Dz.U. 1992 nr 36 poz. 155); http://prawo.sejm.gov.pl/isap.nsf/DocDetails.xsp?id=WDU19920360155 [dostęp 19.11.2017 r.]. 